\title{
Amplification of DNA from Whole Blood
}

\author{
J. Burckhardt
}

\begin{abstract}
Roche Diagnostic Systems, Business Unit Immunochemistry, F. Hoffmann-La Roche Ltd., CH-4002 Basel, Switzerland
\end{abstract}
\begin{abstract}
A method is described for the amplification by PCR of human chromosomal DNA sequences from whole blood samples. Various amounts of blood samples, with either EDTA, citrate, or heparin used as the anticoagulant, have been used to determine optimal PCR conditions for each type of sample. Up to $80 \%$ ( $\mathrm{vol} / \mathrm{vol}$ ) of whole blood sample is tolerated in PCR with Taq polymerase. Amplification from whole blood requires the optimization of salt $\left(\mathrm{K}^{+}\right.$and $\mathbf{M g}^{++}$) according to sample volume and type of anticoagulant used. Pretreatment of fresh blood samples to lyse the leukocytes is required for EDTA-treated blood samples and is beneficient in PCR with heparin- and citrate-treated blood samples to obtain maximal amplicon amounts. A satisfactory method of pretreating samples is freeze/thawing. In addition, EDTAtreated blood samples require a heat treatment before PCR for maximal amplicon synthesis. It appears that purification of the DNA is not necessary for any of the whole blood samples analyzed by PCR. Results of amplification reactions from unpurified hepatitis B virus (HBV) sequences of whole sera samples are shown also.
\end{abstract}

$\mathbf{W}$ hole blood, plasma, and sera represent, by far, the most commonly used sample types in the diagnostic field. Because PCR inhibitors in blood samples ${ }^{(1)}$ have been described, generally, it is accepted that a careful purification of nucleic acids is required from such samples before PCR analysis can be performed. Classical methods for nucleic acid purification from clinical samples involve reagents and steps like organic solvents, denaturing agents, detergents, centrifugation, and precipitation, ${ }^{(2,3)}$ many of which are not compatible with heat-stable DNA polymerases nor desired in future applications with automated PCR systems. Thus, a simple sample preparation method allowing DNA analysis by PCR from whole blood would be valuable.

Different groups have succeeded in using small amounts of unpurified blood samples as substrate for PCR. Amplification of DNA from $1 \mu \mathrm{l}$ to $2 \mu \mathrm{l}$ of unpurified blood in $100-\mu$ l reactions was obtained after a cyclic thermal pretreatment of the samples at $95^{\circ} \mathrm{C}$ and $55^{\circ} \mathrm{C},{ }^{(4)}$ while it was observed that $\mathrm{Tth}$ but not Taq polymerase will amplify DNA from small samples of unpurified and untreated blood. ${ }^{(5)}$

The work presented here describes conditions under which chromosomal sequences can be amplified from unpurified blood using EDTA, heparin, or citrate as anticoagulants. Sample volumes constituted $50 \%$ or more of the PCR assay.

\section{MATERIALS AND METHODS}

\section{PCR Buffer and Solution}

The $10 \times$ concentrated buffers of the $\mathrm{L}$ series contain: $50 \mathrm{~mm}$ tricine $(\mathrm{N}$-[Tris(hydroxymethyl)-methyl]-glycine), at $25^{\circ} \mathrm{C}$ (pH 8.8); $15 \mathrm{~mm} \mathrm{MgCl}_{2} ; 0.5 \%$
Tween 20; and various $\mathrm{KCl}$ concentrations: buffer $10 \times \mathrm{LO}, 0 \mathrm{mM} \mathrm{KCl}$; buffer $10 \times \mathrm{L} 1,100 \mathrm{~mm} \mathrm{KCl}$; buffer $10 \times \mathrm{L} 2,200$ $\mathrm{mM} \mathrm{KCl}$; and so forth up to buffer $10 \times$ $\mathrm{L} 15,1500 \mathrm{~mm} \mathrm{KCl}$.

The buffers of the LM series have a tenfold higher $\mathrm{MgCl}_{2}$ concentration of $150 \mathrm{~mm}$, but are otherwise identical with the buffers of the L series. The $10 \times$ concentrated solution $\mathrm{T}$ contains $15 \mathrm{~mm}$ $\mathrm{MgCl}_{2}$ and $0.5 \%$ Tween 20 .

\section{PCR Setup}

Reactions were prepared in a laminar flow hood, according to the contamination precautions suggested. ${ }^{(6)}$ The frozen blood samples were thawed at room temperature. An aliquot was added in $0.5-\mathrm{ml}$ reaction tubes to $4.5-\mu \mathrm{l} 10 \times$ buffer and autoclaved water to obtain a total volume of $45 \mu$ l. The volume was covered with 2 drops of mineral oil.

Sample pretreatment was performed by cycling $\sim 20$ times between $90^{\circ} \mathrm{C}$ and $50^{\circ} \mathrm{C}$ for $1 \mathrm{~min}$ each in the thermocycler (Landgraf TPS 5/9). A 5- $\mathrm{ll}$ PCR mix was then added at room temperature containing $0.5 \mu \mathrm{l}$ of a $10 \mathrm{~mm}$ solution of the dNTP (Pharmacia), $0.5 \mu$ l of the $10 \times$ PCR buffer, 1.25-2.5 units of Taq polymerase (usually Super-Taq from P.H. Stehelin, Switzerland), $0.5 \mu \mathrm{l}$ of each primer (50 $\mu \mathrm{M})$ and water to a final volume of $5 \mu \mathrm{l}$. Thermocycler conditions for PCR were $30 \mathrm{sec}$ at $93^{\circ} \mathrm{C}$, then $30 \mathrm{sec}$ at annealing temperature, and $90 \mathrm{sec}$ at $72^{\circ} \mathrm{C}$, usually for $\sim 40$ cycles. Reaction tubes were briefly centrifuged after PCR and 7-10 $\mu \mathrm{l}$ of the supernatant below the oil layer were loaded on $2 \%$ TBE agarose gels. The $50 \mu \mathrm{l}$ reactions containing $>30 \%$ and more of whole blood ( $\mathrm{vol} / \mathrm{vol})$ were diluted after amplification with $30 \mu \mathrm{l}$ of water before centrifugation. Amplicon detection was by ethidium bromide staining of the DNA in agarose gels. 


\section{Primer Sequences and Annealing Temperatures (AT)}

Primers were synthesized in house on a Cyclone (Milligen) apparatus. Primers were used after deblocking without further purification. (1) HLA primer GH26/ 27. ${ }^{(7)} \mathrm{AT}: 60^{\circ} \mathrm{C}$; amplicon size $242 \mathrm{bp}$. (2) Primers for blood factor IX. ${ }^{(8)} \mathrm{JR} 35^{\prime}$ AGG ACC GGG CAT TCT AAG CAG TTT A 3'; JR4 5' CAG TTT CAA CTT GTT TCA GAG GGA A 3'; AT: $55^{\circ} \mathrm{C}$; amplicon 234 bp. (3) Primer for hepatitis B virus. MD $1225^{\prime}$ CTC TCA ATT TTC TAG GGG GA 3'; MD $1235^{\prime}$ AGC AGC AGG ATG AAG AGG AA 3'; amplicon 151 bp.

\section{RESULTS}

The conditions for DNA PCR from whole blood samples were optimized in two steps (described in sections A and B). An extensive pretreatment of the unpurified samples was performed (see section A) by freeze/thawing once and subsequently cycling 20 times for 1 -min each between $90^{\circ} \mathrm{C}$ and $50^{\circ} \mathrm{C}$, to reach maximal lysis of the white blood cells before amplification. This sample pretreatment enabled the determination of optimal salt concentrations, assay sensitivity, and maximal whole blood sample volumes tolerated in PCR assays. Subsequently, fresh whole blood samples were used to determine the minimal conditions of sample pretreatment for PCR of leukocytes (section B).

\section{A1. Optimal $\mathrm{KCl}$ and $\mathrm{MgCl}_{2}$ Concentrations in PCR with Whole Blood Samples}

It has been shown that Taq polymerase has a $\mathrm{KCl}$ optimum of $50 \mathrm{~mm} .{ }^{(9)}$ Blood has a $\mathrm{K}^{+}$and $\mathrm{Na}^{+}$concentration of 124 mM. ${ }^{(10)}$ Thus, the influence on PCR of DQA1 of various monovalent salt concentrations was compared using as substrate either $20 \mathrm{ng}$ human DNA or $20 \%$ whole blood with EDTA as anticoagulant (data not shown). A broad salt optimum was found with best salt concentrations in the PCR buffer ranging from $50 \mathrm{~mm}$ to $>100 \mathrm{mM} \mathrm{KCl}$ for purified DNA and from $0 \mathrm{~mm}$ to $90 \mathrm{~mm} \mathrm{KCl}$ for whole blood samples. $\mathrm{KCl}$ concentrations $<50 \mathrm{~mm}$ in the buffer yield specific products only with whole blood samples but not with purified DNA as substrate. A concentration of $150 \mathrm{~mm} \mathrm{KCl}$ allows some DNA synthesis with purified DNA, but not with whole blood samples.

Then the optimal salt concentration was determined for PCR with $5-50 \%$ of pretreated whole blood (Table 1). All three types of anticoagulants in the blood allow specific amplicon synthesis for the tested volumes. The PCR buffer with the usual $\mathrm{KCl}$ concentration of 50 mM enables specific DNA synthesis in the presence of up to 30\% EDTA-treated blood and up to $50 \%$ heparin-treated blood, while high $\mathrm{KCl}$ (and high $\mathrm{MgCl}_{2}$ ) concentrations are required for the amplification from citrate-treated blood samples.

The minimum $\mathrm{KCl}$ requirement was determined by replacing the PCR buffer with a solution $\mathrm{T}$ containing only $\mathrm{MgCl}_{2}$ and Tween 20 , but no buffering substance or $\mathrm{KCl}$. This solution allows specific and efficient amplicon synthesis from large volumes of EDTA- and heparin-treated blood, but not of citratetreated blood.

Optimization of $\mathrm{MgCl}_{2}$ concentrations for unpurified citrate-treated blood (20\% and 50\% sample volumes) gave best values with $\mathrm{MgCl}_{2}$ ranging between 4.5-15 $\mathrm{mm}$, in the presence of $50-100$ $\mathrm{mM} \mathrm{KCl} \mathrm{(data} \mathrm{not} \mathrm{shown).} \mathrm{Efficient}$ DQA1 synthesis is found with $1.5 \mathrm{~mm}$ $\mathrm{MgCl}_{2}$ in the PCR buffer in reactions with all volumes of heparin blood samples. In amplifications with large EDTAtreated blood samples, the minimal
$\mathrm{MgCl}_{2}$ concentration appears to be $\sim 1$ $\mathrm{mm}$ above the EDTA concentration, which ranges in undiluted EDTA-treated blood between 3.5 and $4.0 \mathrm{~mm}$.

\section{A2. Sensitivity of PCR Assays with Whole Blood Samples}

Human EDTA-treated blood was mixed in various ratios with sheep EDTAtreated blood to analyze the sensitivity of the PCR assay with $20 \%$ unpurified blood sample (Fig. 1). It was established previously that the primer pair GH 26/27 is specific for human DQA1 and gives no PCR product with the homologous gene of sheep. The results show that $10 \mathrm{nl}$ of human blood (with $\sim 50$ leukocytes) in a $10-\mu l$ sheep blood sample is sufficient to yield a positive signal in 40 amplification cycles, even when staining amplicons by ethidium bromide in agarose gels, an unsensitive DNA detection procedure.

\section{A3. Confirmatory Experiments}

Whole blood samples ( $20 \%$ and $40 \% \mathrm{vol} /$ vol) from 19 donors were assayed in 50$\mu l$ amplification reactions: ten samples with EDTA-treated blood (Fig. 2), five with heparin-treated blood (Fig. 3A), and four with citrate-treated blood (data not shown). No specimens showed detectable inhibition of PCR.

TABLE 1 Optimization of Salt Concentrations in PCR Assays of DQA1 with 5-50\% Pretreated EDTA-, Citrate-, or Heparin-treated Blood

\begin{tabular}{|c|c|c|c|c|c|c|}
\hline & \multicolumn{6}{|c|}{ Sample percentage $(\mathrm{vol} / \mathrm{vol})$ in PCR } \\
\hline & $\overline{5}$ & 10 & 20 & 30 & 40 & 50 \\
\hline \multicolumn{7}{|l|}{ Heparin-treated blood } \\
\hline $0 \mathrm{mM} \mathrm{KCl}(\mathrm{T})$ & - & ++ & $+t$ & ++ & ++ & ++ \\
\hline $50 \mathrm{~mm} \mathrm{KCl}$ (L5) & ++ & ++ & ++ & ++ & ++ & ++ \\
\hline \multicolumn{7}{|l|}{ EDTA-treated blood } \\
\hline $0 \mathrm{~mm} \mathrm{KCl} \mathrm{(T)}$ & $-\pi$ & $+/ \mathrm{U}$ & ++ & ++ & ++ & ++ \\
\hline $50 \mathrm{~mm} \mathrm{KCl}(\mathrm{L} 5)$ & ++ & ++ & ++ & ++ & - & - \\
\hline \multicolumn{7}{|l|}{ Citrate-treated blood } \\
\hline $0 \mathrm{~mm} \mathrm{KCl} \mathrm{(T)}$ & - & - & - & - & - & - \\
\hline $0 \mathrm{mM} \mathrm{KCl}, 15 \mathrm{mM} \mathrm{Mg}^{++}(\mathrm{LOM})$ & $-/ U$ & $-/ U$ & $-N$ & $+N$ & $++\pi$ & $++/ U$ \\
\hline $50 \mathrm{~mm} \mathrm{KCl} \mathrm{(L5)}$ & ++ & ++ & + & - & - & - \\
\hline $50 \mathrm{~mm} \mathrm{KCl}, 15 \mathrm{~mm} \mathrm{Mg}^{++}(\mathrm{L} 5 \mathrm{M})$ & $-/ U$ & $+/ \mathrm{U}$ & $++/ \mathrm{U}$ & ++ & ++ & ++ \\
\hline $100 \mathrm{~mm} \mathrm{KCl}(\mathrm{L} 10)$ & ++ & ++ & - & - & - & - \\
\hline $100 \mathrm{mM} \mathrm{KCl}, 15 \mathrm{mM} \mathrm{Mg}^{++}(\mathrm{L} 10 \mathrm{M})$ & ++ & ++ & ++ & ++ & ++ & + \\
\hline $150 \mathrm{mM} \mathrm{KCl}, 15 \mathrm{mM} \mathrm{Mg}^{++}(\mathrm{L} 15 \mathrm{M})$ & ++ & ++ & ++ & + & + & - \\
\hline
\end{tabular}

Amplification in 40 cycles of DQA1 from whole blood samples in varying $\mathrm{KCl}$ and $\mathrm{MgCl}_{2}$ concentrations (for PCR buffer compositions, see Materials and Methods).

$(-)$ No amplicon visible on agarose gel; $(+)$ low amount of amplicon visible; $(++)$ large or very large amounts of amplicon visible; (U) unspecific DNA synthesis. 
Confirmation of the results obtained for the DQA1 amplicon was sought with the primers $\mathrm{J} 3 / 4$ specific for a sequence of the blood factor IX. ${ }^{(8)}$ Various sample volumes of heparin-treated blood from five different donors were tested, all giving the expected amplicon of $234 \mathrm{bp}$ (data not shown).

In addition, PCR for DQA1 with heparin-treated blood was performed in reactions where $T a q$ polymerase was substituted with Pfu, rTth, or Vent, all three enzymes giving positive results (data not shown).

\section{A4. Amplification of Large Volumes of Blood Samples}

The maximal sample volume of citrateor EDTA-treated whole blood which gave visible amplicon yields was $60 \%$ (data not shown). Heparin-treated blood on the other hand is better tolerated by Taq polymerase: amplicons are even formed (with decreasing efficiency) in reactions containing up to $82 \%$ blood (Fig. 3B).

A further increase in whole blood sample volume analyzed in a single amplification reaction was obtained by increasing the sample and reaction volumes at the same time. PCR experiments

\section{$\begin{array}{lllll}87 & 5 & 3 & 1 & M\end{array}$}

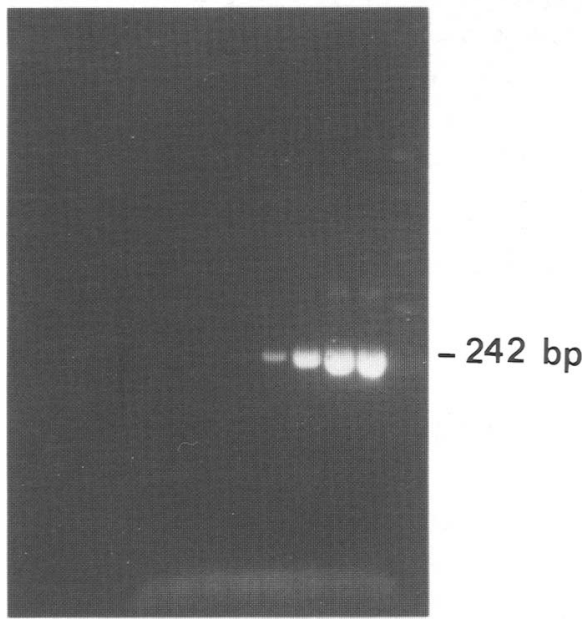

FIGURE 1 Sensitivity of PCR assay with $10 \mu \mathrm{l}$ unpurified blood. Human EDTA-treated blood was mixed with sheep EDTA-treated blood in various concentrations, pretreated, and amplified with 40 cycles in $\mathrm{L} 2$ buffer. The following amounts of human blood were present per reaction: (lane 1) $10 \mu \mathrm{l}$; (lane 2) 1 $\mu \mathrm{l}$; (lane 3) $100 \mathrm{nl}$; (lane 4) $10 \mathrm{nl}$; (lane 5) $1 \mathrm{nl}$; (lane 6) $0.1 \mathrm{nl}$; (lane 7) $0.01 \mathrm{nl}$. (Lane 8) PCR with $10 \mu \mathrm{l}$ sheep blood only. (M) Marker.

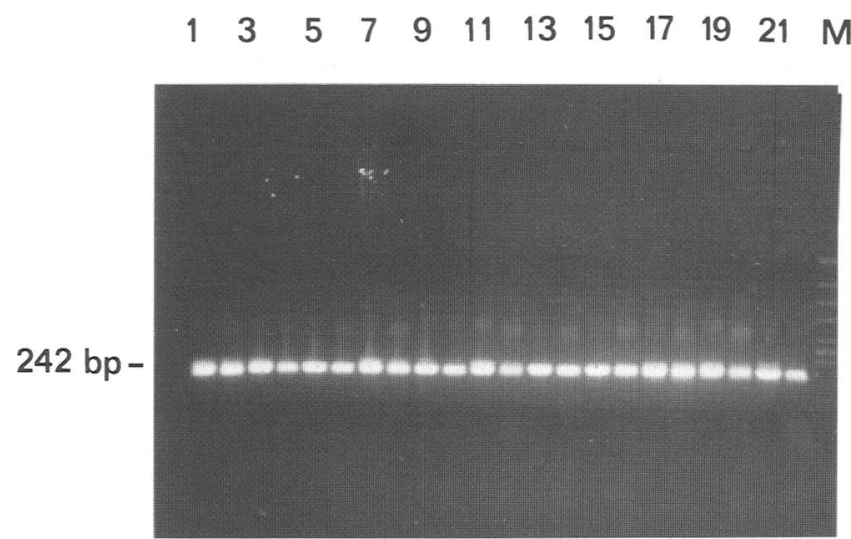

FICURE 2 DQA1 was amplified from $10 \mu \mathrm{l}$ and $20 \mu \mathrm{l}$, respectively, of pretreated EDTA-treated blood from 10 different blood donors in Lo buffer for 40 cycles. Lanes with even number: $20 \%$ blood samples per PCR. Lanes with uneven numbers: 40\% blood samples per PCR. (Lanes 1 and 2) Donor 1; (lanes 3 and 4) donor 2; and so on. Blood from donor 7 was assayed in duplicate (lanes 13-16).

were performed using $200 \mu \mathrm{l}$ of whole heparin-treated blood in reaction volumes of $500 \mu \mathrm{l}$. All reagents were used in the same proportion as in the usual $50-\mu l$ reaction. Cycling conditions were expanded from $3 \mathrm{~min}$ to $10 \mathrm{~min}$. Comparable amplicon yields were obtained with samples of different donors analyzed in large or small reaction volumes (Fig. 3A and data not shown).

\section{B. Amplification with Fresh Blood Samples}

The results mentioned so far were obtained with blood samples aliquoted 2 days after donation and stored frozen before performing PCR after sample pretreatment. The following experiment was designed to analyze minimal pretreatment conditions for fresh, whole blood samples.

Samples stored at room temperature for $2 \mathrm{hr}$ (heparin- and citrate-treated blood) or $24 \mathrm{hr}$ (EDTA-treated blood) after donation were used without any pretreatment, after freeze/thawing in dry ice, or after freeze/thawing and cycling 5 times between $90^{\circ} \mathrm{C}$ and $50^{\circ} \mathrm{C}$ (Table 2 ). It appears that heparin- and citratetreated blood samples can be used directly for PCR, but that pretreatment by freezing is giving optimal amplicon synthesis. Minimal sample pretreatment for EDTA-treated blood consists of a freeze/ thaw step. Further pretreatment by from 5 up to 15 additional heat cycles is necessary for optimal amplicon yields with EDTA-treated blood.
Alternatively, storing heparin- and citrate-treated blood samples for $\sim 5$ days at room temperature before PCR, gives high amplicon yields without any sam-

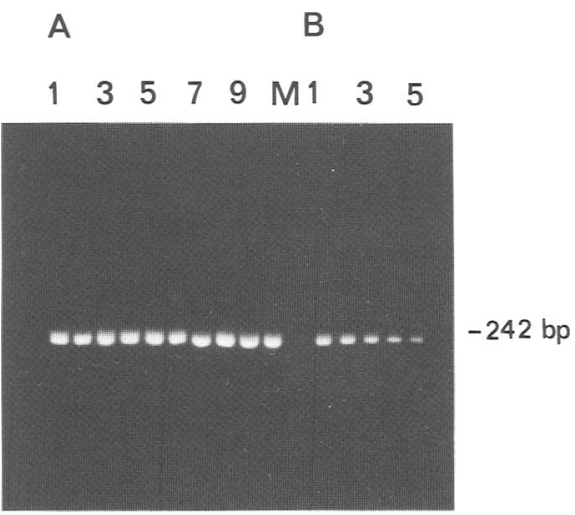

FIGURE 3 Amplification of DQA1 from large heparin-treated blood samples. (A) $100 \mu l$ and $200 \mu \mathrm{l}$, respectively, of pretreated heparintreated blood from 5 different donors was used as substrate in PCR assays of $500-\mu 1$ reaction volume, with solution T as PCR buffer. Amplification was for 40 cycles of $10 \mathrm{~min}$ each, with $3 \mathrm{~min} 20 \mathrm{sec}$ for each step (denaturation at $92^{\circ} \mathrm{C}$, annealing at $60^{\circ} \mathrm{C}$, and elongation at $\left.72^{\circ} \mathrm{C}\right)$. The supernatant $(7 \mu \mathrm{l})$ was loaded after a 1 -min centrifugation on a $2 \%$ agarose gel as in the other experiments. Lanes with even numbers: $200 \mu \mathrm{l}$ blood (or $40 \% \mathrm{vol} /$ vol) present in the amplification reaction; lanes with uneven numbers: $100 \mu$ l blood per reaction. (Lanes 1 and 2 ) Blood from donor 1 ; (lanes 3 and 4 ) donor 2; and so on. (B) Amplification reactions with very large fractions $(40-82 \% \mathrm{vol} / \mathrm{vol})$ of pretreated blood were analyzed. Reactions of $50 \mu \mathrm{l}$ were set up with 10 $\mu \mathrm{l}, 20 \mu \mathrm{l}, 30 \mu \mathrm{l}, 35 \mu \mathrm{l}$, and $41 \mu \mathrm{l}$ of sample, respectively, for 40 cycles, with solution $T$ replacing PCR buffer (lanes 1-5, respectively). 
TABLE 2 Determination of Minimal Sample Pretreatment Necessary for Amplification of DQA1 from Fresh Blood Samples of Two Donors, A and B

\begin{tabular}{lccc}
\hline & \multicolumn{2}{c}{ Sample pretreatment before PCR } \\
\cline { 2 - 3 } & $\begin{array}{l}\text { no pretreatment }(-), \\
\text { freezing }(+)\end{array}$ & $\begin{array}{l}5 \text { denaturation } \\
\text { cycles }\left(90-50^{\circ} \mathrm{C}\right)\end{array}$ & $\begin{array}{c}\text { Amplicon } \\
\text { synthesis }\end{array}$ \\
\hline EDTA-treated blood & - & - & - \\
A,B & + & - & ++ \\
A,B & + & + & ++ \\
A,B & & - & + \\
Heparin- or & - & - & ++ \\
citrate-treated blood & + & + & ++ \\
A,B & + & - & \\
A,B & + & & \\
A,B & & & \\
\hline
\end{tabular}

Amplification for 43 cycles in buffer L3 (EDTA- and heparin-treated blood) or L10M (citratetreated blood) of DQA1 from $20 \%(\mathrm{vol} / \mathrm{vol})$ fresh whole blood without any pretreatment or pretreated as indicated. Freezing was done for $30 \mathrm{~min}$ at $-70^{\circ} \mathrm{C}$. All results for blood samples of donor A and B were identical. Symbols for the results are as in Table 1.

ple pretreatment, while aged, EDTAtreated blood samples still require freeze/ thawing and from 5 to 15 heat cycles for optimal amplification (data not shown).

\section{Amplification of Hepatitis B Virus (HBV) from Whole Serum}

Preliminary experiments showed that DQA1 can be amplified in reactions with $10 \%$ to $40 \%$ serum spiked with $20 \mathrm{ng}$ human DNA and buffer L5 containing $50 \mathrm{~mm} \mathrm{KCl}$ after serum pretreatment (freeze/thawing and 20 cycles of pretreatment at $\left.90^{\circ} \mathrm{C} / 50^{\circ} \mathrm{C}\right)($ data not shown). The sensitivity of the new procedure was further analyzed for PCR of HBV DNA: serum with a titer of $15 \times 10^{6} \mathrm{HBV}$ genomes per microliter (serum and HBV titer determination was provided by $\mathrm{Dr}$. U. Hennes and B. Wolf) was diluted to various concentrations with a HBV-negative control serum. Aliquots of $10 \mu \mathrm{l}$ of sera were pretreated as described and amplified in $50-\mu$ l reactions with $\mathrm{HBV}$ specific primers (Table 3). Samples containing $>1500$ viral genomes gave visible amounts of the expected amplicon of 151 bp after 40 PCR cycles.

\section{DISCUSSION}

DNA PCR by Taq polymerase of sequences from pretreated, whole blood samples treated with heparin, EDTA, or citrate as anticoagulant is possible, even with samples contributing $50 \%$ or more to the reaction volume. According to the present study only two variables have to be taken into account when amplifying DNA from whole blood: (1) Accessibilty of target sequence to the PCR reagents. (2) Adaptation of salt concentration to the enzyme requirements. A further factor, inactivation of inhibitor(s) of the enzymatic amplification reaction, seems not to be necessary (see below).

\section{Accessibility}

Cellular or viral DNA, present in vivo in a protected form in cells or virus, is not readily accessible to all PCR reagents. This barrier is overcome by lysing the cells or virus. The optimal lysis treatment differs depending on the type of anticoagulant used (Table 2). It could be shown that chromosomal DNA from cells in heparin- or citrate-treated blood

TABLE 3 Amplification of DNA

Sequence from $\mathrm{HBV}$ from Whole Serum

\begin{tabular}{llc}
\hline & $\begin{array}{l}\text { Number of HBV genomes } \\
\text { per PCR assay }\end{array}$ & $\begin{array}{c}\text { Amplicon } \\
\text { synthesis }\end{array}$ \\
\hline 1 & $1.5 \times 10^{6}$ & ++ \\
2 & $1.5 \times 10^{5}$ & ++ \\
3 & $1.5 \times 10^{4}$ & ++ \\
4 & 1500 & + \\
5 & 150 & - \\
6 & 15 & - \\
7 & negative control serum & - \\
\hline
\end{tabular}

Amplification of HBV from $20 \%$ ( $\mathrm{vol} / \mathrm{vol}$ ) pretreated sera was in buffer L5 for 40 cycles. Symbols used are as in Table 1. is released very easily in PCR buffer with Tween 20 .

\section{Salt concentration}

The $\mathrm{Na}^{+}$and $\mathrm{K}^{++}$concentration of whole blood amounts to an average of $124 \mathrm{mM}$, the $\mathrm{MgCl}_{2}$ concentration averages $5.1 \mathrm{~mm}$. The respective values for plasma are $145 \mathrm{~mm}$ and $1.6 \mathrm{~mm} .^{(10)}$ The contribution of monovalent salt for the anticoagulant heparin is below $1 \mathrm{~mm}, 10$ mм for EDTA as a tripotassium salt, and $36 \mathrm{~mm}$ for trisodium citrate. ${ }^{(11)}$ Because of the salt concentration present in PCR with large blood samples, it appears unnecessary or even inhibitory to add more potassium to PCR assays with heparin- or EDTA-treated blood samples, while the requirement of potassium for citrate blood samples is very high (overview in Table 4).

\section{Blood as Inhibitor of PCR}

The published observations on inhibition of PCR using whole blood (type of anticoagulant often not reported) and our own results need not be contradictory. ${ }^{(1-3,12-14)}$ Citrate-treated blood, which is the most commonly used blood treatment in diagnostics, requires an unusually high salt buffer for PCR. Leukocytes in EDTA-treated blood on the other hand are difficult to lyse. It seems likely that PCR with EDTA- or citrate-treated blood could have given the negative results for these reasons rather than for the presence of some inhibitory substance. Heparin-treated whole blood, while appearing to be the best suited type of whole blood sample for DNA PCR, is unlikely to have been used because of the well-known inhibitory action of heparin

TABLE 4 Monovalent Salt Necessary in PCR Buffer for Optimal Amplification of DNA from Various Amounts of Whole Blood Samples

\begin{tabular}{lrrrrr}
\hline & \multicolumn{5}{c}{ Sample volume (\%) } \\
\cline { 2 - 6 } Whole blood & 10 & 20 & 30 & 40 & 50 \\
\hline EDTA-treated & 50 & 25 & 0 & 0 & 0 \\
Heparin-treated & 70 & 50 & 20 & 0 & 0 \\
Citrate-treated & 100 & 100 & 80 & 50 & 50 \\
\hline
\end{tabular}

Optimal $\mathrm{K}^{+}$concentrations $(\mathrm{mM})$ for PCR with whole blood samples containing different anticoagulants. 
in PCR with purified DNA or RNA substrate. ${ }^{(15)}$ Heparin inhibits restriction enzymes and polymerases due to binding with higher affinity of these enzymes to heparin than to the DNA. ${ }^{(16)}$ It is a surprising result that heparin is not interfering in whole blood PCR in contrast with PCR with partially purified DNA or RNA with copurified heparin where inhibition by heparin could be overcome by digestion of the sample using heparinase. ${ }^{(17)}$ It is assumed that albumin ${ }^{(18,19)}$ or other blood components absent in purified samples are able to sequester heparin during PCR with whole blood samples.

Also, it is unlikely that the results shown in this work are caused by an artifact. Contamination, the main cause of false-positive results in PCR, is not a crucial aspect for experiments designed to overcome an inhibitory action of a sample. In any case the contamination level in the experiments shown is less than the number of DNA copies present in about 50 leukocytes (Fig. 1). In addition, the fact that efficient amplicon synthesis in PCR with large blood samples is possible with different polymerases and with different target sequences argue against the probability that the described observations would be valid in special cases only. Finally, and most important in this regard, are two very recent publications in which PCR is described with specific types of large whole blood samples. ${ }^{(20,21)}$

The amplicons synthesized in the presence of whole serum (and sometimes plasma; data not shown) are often unstable, an observation not made for whole blood PCR: amplification products of sera cannot be stored for $24 \mathrm{hr}$ at room temperature unless stabilized by adding EDTA (final concentration, 20 $\mathrm{mM})$ or proteinase $\mathrm{K}(50 \mu \mathrm{g} /$ reaction $)$. In addition, samples sometimes become viscous, a fact that seems not to interfere with DNA amplification, but made amplicon detection difficult. Dilution of the samples after PCR with $30 \mu l$ water and/or proteinase $\mathrm{K}$ digestion for $30 \mathrm{~min}$ at $56^{\circ} \mathrm{C}$ helped to reduce this problem. Whole blood samples never turned viscous nor had unstable amplicons, even in reactions with large blood volumes where nearly all reaction volume was taken up by precipitated blood components.

Other applications of the new procedure: PCR from very large blood samples
$(200 \mu \mathrm{l})$ in $500-\mu \mathrm{l}$ reactions (this work), from dried blood samples, ${ }^{(22)}$ or whole serum samples ${ }^{(23,24)}$ (and this work) now have been described at least to some extent for PCR with unpurified substrate.

In conclusion, heparinized whole blood samples appear to be the best suited type of whole blood for DNA PCR with Taq polymerase: (1) Heparintreated blood can be added directly to a PCR assay. (2) Taq tolerates up to $82 \%$ heparin blood in a PCR assay. (3) Amplicon synthesis by $T a q$ is efficient with heparin-treated blood. (4) No decrease in specificity or efficiency of amplicon synthesis was found which was caused by different sample volumes; that is, low sensitivity of Taq to variation of salt or other reaction components in PCR with heparin-treated blood.

\section{REFERENCES}

1. Higuchi, R. 1989. Simple and rapid preparation of samples for PCR. In PCR technology (ed. H.A. Erlich), pp. 31-38. Stockton Press.

2. Loparev, V.N., M.A. Cartas, C.E. Monken, A. Velpandi, and A. Srinivasan. 1991. An efficient and simple method of DNA extraction from whole blood and cell lines to identify infectious agents. I. Virol. Methods 34: 105-112.

3. Walsh, P.S., D.A. Metzger, and R. Higuchi. 1991. Chelex 100 as a medium for a simple extraction of DNA for PCR-based typing from forensic material. BioTechniques 10: $506-513$.

4. Mercier, B., C. Gaucher, O. Feugeas, and C. Mazurier. 1990. Direct PCR from whole blood, without DNA extraction. Nucleic Acids Res. 18: 5908.

5. Panacchio, M. and A. Lew. 1991. PCR in the presence of $8 \%(\mathrm{v} / \mathrm{v})$ blood. Nucleic Acids Res. 19: 1151.

6. Kwok, S. and R. Higuchi. 1989. Precautions for PCR. Nature 339: 237-238.

7. Erlich, H.A. and T.L. Bugawan. 1989. HLA class II gene polymorphism: DNA typing, evolution, and relationship to disease susceptibility. In PCR technology (ed. H.A. Erlich), pp. 193-208. Stockton Press.

8. Reiss, J., U. Neufeldt, K. Wieland, and B. Zoll. 1990. Diagnosis of haemophilia B using the polymerase chain reaction. Blut 60: $31-36$.

9. Gelfand, D. 1989. Taq DNA polymerase. In PCR technology (ed. H.A. Erlich), pp. 17-22. Stockton Press.

10. In Documenta Geigy 1970. Scientific tables: Blood; inorganic substances (ed. K. Diem and C. Lentner), edition 7, pp. 561568, published by J.R. Geigy S.A., Basle.

11. NCCLS Document H1-A3: Evacuated tubes for blood specimen collection, third edition, 1991. Vol. 11/9, pp. 1-17.

12. Beutler, E., T. Gelbart, and W. Kuhl. 1990. Interference of heparin with the polymerase chain reaction. BioTechniques 9: 166 .

13. Holodny, M., S. Kim, D. Katzenstein, M. Konrad, E. Groves, and T.C. Merigan. 1991. Inhibition of human immunodeficiency virus gene amplification by heparin. J. Clin. Microbiol. 29: 676-679.

14. Wang, J.-T., T.-H. Wang, J.-C. Sheu, S.-M. Lin, J.-T. Lin, and D.-S. Chen. 1992. Effects of anticoagulants and storage of the blood samples on efficacy of the polymerase chain reaction assay for hepatitis C virus. J. Clin. Microbiol. 30: 750-753.

15. Chen, J., L.A. Herzenberg, and L.A. Herzenberg. 1990. Heparin inhibits EcoRI endonuclease cleavage of DNA at certain EcoRI sites. Nucleic Acids Res. 18: 32553258.

16. Bickle, T.A., V. Pirrotta, and R. Imber. 1977. A simple, general procedure for purifying restriction endonucleases. Nucleic Acids Res. 4: 2561-2572.

17. Imai, H., O. Yamada, S. Morita, S. Suehiro, and T. Kurimura. 1992. Detection of HIV-1 RNA in heparanized plasma of HIV-1 seropositive individuals. J. Virol. Methods 36: 181-184.

18. Hagelberg, E. and B. Sykes. 1989. Ancient bone DNA amplified. Nature 342: 485.

19. Higuchi, R. 1992. Dr. Russ problem corner. In Ancient DNA newsletter (ed. R.K. Wayne and A. Cooper), vol. 1, pp. 6-8. Institute of Zoology, The Zoological Society of London, London.

20. Panaccio, M., M. Georgesz, and A.M. Lew. 1993. FoLT PCR: A simple PCR protocol for amplifying directly from whole blood. BioTechniques 14: 238-243.

21. McCusker, J., M.T. Dawson, D. Noone, F. Gannon, and T. Smith. 1992. Improved method for direct PCR amplification from whole blood. Nucleic Acids Res. 20: 6747.

22. Nelson, P.V., W.F. Carey, and C.P. Morris. 1990. Gene amplification directly from Guthrie blood spots. Lancet 336: 14511452.

23. Frickhofen, N. and N.S. Young. 1991. A rapid method of sample preparation for the detection of DNA viruses in human serum by polymerase chain reaction. I. $\mathrm{Vi}$ rol. Methods 35: 65-72.

24. Cheyrou, A., C. Guyomarc'h, P. Jasserand, and P. Blouin. 1991. Improved detection of HBV DNA by PCR after microwave treatment of serum. Nucleic Acids Res. 19: 4006 .

Received September 20. 1993; accepted in revised form December 16, 1993. 


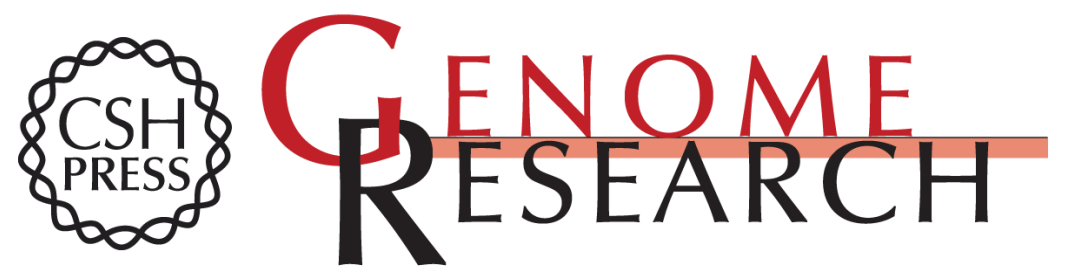

\section{Amplification of DNA from whole blood.}

J Burckhardt

Genome Res. 1994 3: 239-243

References This article cites 18 articles, 2 of which can be accessed free at:

http://genome.cshlp.org/content/3/4/239.full.html\#ref-list-1

\section{License}

Email Alerting Receive free email alerts when new articles cite this article - sign up in the box at the Service top right corner of the article or click here.

\section{Affordable, Accurate Sequencing.}

To subscribe to Genome Research go to: https://genome.cshlp.org/subscriptions 